\title{
AS MODALIDADES DE TRADUÇÃO APLICADAS À INTERPRETAÇÃO EM LÍNGUA DE SINAIS BRASILEIRA
}

\author{
Silvana Nicoloso* \\ Universidade Federal de Santa Catarina \\ Viviane Maria Heberle** \\ Universidade Federal de Santa Catarina
}

\begin{abstract}
Resumo: Este artigo foi desenvolvido a partir de um capítulo pertencente à tese de doutorado ${ }^{1}$ da primeira autora, para uma discussão mais pontual, relacionada à prática da interpretação simultânea em Língua de Sinais Brasileira com base nas Modalidades de Tradução descritas por Francis Aubert (1998). O texto interpretado denomina-se "Descobrindo quem somos nós", extraído do livro "Aprender a ver: o ensino da língua de sinais americana como segunda língua" de autoria de Sherman Wilcox e Phyllis Perrin Wilcox, com tradução de Tarcísio de Arantes Leite. As referidas interpretações foram realizadas em estúdio fechado e com a aprovação do Comitê de Ética em Pesquisas com Seres Humanos da Universidade Federal de Santa Catarina e os dados coletados na pesquisa foram analisados por meio do software ELAN. Resultados indicam que o exercício de utilizar uma metodologia de análise que se aproprie das Modalidades de
\end{abstract}

\footnotetext{
* Educadora Especial. Doutoranda em Estudos da Tradução pela UFSC. Professora Efetiva de Tradução no Instituto Federal de Santa Catarina, em Palhoça, Santa Catarina, Brasil.silnic71@yahoo.com.br

** Doutora em Letras/Inglês pela UFSC, com pós-doutorado na University of Sydney, Austrália. Professora Titular do Departamento de Língua e Literatura Estrangeiras da UFSC. É docente no Curso de Letras/Inglês e nos Programas de Pós-Graduação em Inglês e em Estudos da Tradução da UFSC, em Florianópolis, Santa Catarina, Brasil. viviane.heberle@ufsc.br
} 
Tradução contribui para se obter uma visão mais clara entre as semelhanças e diferenças existentes entre os pares linguísticos selecionados.

Palavras-chave: Interpretação simultânea. Língua de Sinais Brasileira. Modalidades de Tradução.

\title{
TRANSLATION MODALITIES APPLIED TO THE INTERPRETATION IN BRAZILIAN SIGN LANGUAGE
}

\begin{abstract}
This article was developed from a chapter in a doctoral thesis from the first author, towards a specific focalized discussion, related to the practice of simultaneous interpretation in Brazilian Sign Language, based on translation modalities as proposed by Aubert (1998). The interpreted text is called "Discovering who we are", extracted from the book Learning to see, by Sherman, Wilcox and Phyllis, and translated by Tarcisio de Arantes Leite. The interpretations were recorded in a media studio, with the official consent from the Ethics Committee for Research with Human Beings at the Federal University of Santa Catarina, Brazil and the data was analyzed by means of the software ELAN. Results indicate that using a research method which considers translation modalities may contribute to obtain a clearer view regarding the similarities and differences between the selected linguistic pairs.
\end{abstract}

Keywords: Simultaneous interpretation. Brazilian Sign Language. Translation modalities.

\section{Introdução}

Para dar início ao tema proposto, é importante apresentar o campo disciplinar geral em que este trabalho se insere, ou seja, os Estudos da Tradução (ET). Considerando os Estudos da Tradução um campo abrangente, é possível contextualizar a presente pesquisa, também, dentro dos Estudos da Interpretação (EI) e, mais especificamente, na área da interpretação de língua de sinais. Pagura (2003) afirma que a tradução e a interpretação são consideradas profissões "gêmeas". Embora não haja dúvidas de que a interpretação envolva um processo de tradução, no sentido geral desse termo, grande parte dos teóricos e profissionais da área da tradução utiliza os termos tradução e interpretação para se referir a duas atividades distintas. 
Assim, levando em conta as várias abordagens teóricas e vertentes metodológicas presentes nos ET e nos EI, pode-se entender a tradução e a interpretação como sendo processos similares e ao mesmo tempo diferentes (COKELY, 1992; PAGURA, 2003; PÖCHHACKER, 2004; ALBIR; ALVES, 2009). A compreensão dessa diferença pode ser traçada a partir da ideia de que, conforme Pagura (2003, p. 210), "o tradutor trabalha com a palavra escrita e o intérprete com a palavra falada". Essa distinção baseia-se na concepção de que o fato do texto ser escrito ou falado define o processo por meio do qual ele será traduzido ou interpretado. No entanto, para Pöchhacker (2004), a interpretação não precisa estar ligada, necessariamente, à tradução oral. Ele afirma que se considerarmos o aspecto de tempo da interpretação, é possível diferenciá -la de outras formas de tradução, sem se recorrer à dicotomia oral versus escrito. Assim, pelo conceito de interpretação trazido por Pöchhacker (2004), percebe-se que ela se diferencia da tradução a partir do simultâneo ou imediato.

Então, de modo geral, tradução e interpretação apresentam modalidades distintas de atuação entre os profissionais, implicando também em diferentes condições de trabalho em virtude do ritmo e do tempo. Assim, diante do caráter deste artigo, que também considera a tradução e a interpretação em língua de sinais como áreas próximas, porém distintas, é relevante mencionar que no contexto proposto serão considerados alguns aspectos do sentido geral de tradução e, em outros momentos, será apresentado o caráter específico de interpretação. Portanto, quando apresentadas às modalidades estudadas por Francis Aubert (1998), será preservado o termo tradução entendendo-o como genérico e quando houver referências à mediação entre o português e a Libras o termo interpretação será o preterido, por entender que a diferença de modalidade possui suas peculiaridades.

Dito isso, o presente trabalho tem o propósito de realizar uma discussão e reflexões sobre questões referentes à interpretação simultânea da Língua Portuguesa (LP) para a Língua de Sinais Brasileira (Libras), relacionando às Modalidades de Tradução ${ }^{2}$ que se 
manifestam durante o ato tradutório. Com vistas a este propósito, os estudos tradutológicos e as Modalidades de Tradução descritas por Aubert (1998) darão suporte para as análises.

Os estudos tradutológicos, conforme Aubert (1998, p. 100),

\begin{abstract}
ocupam-se não apenas da(s) linguagen(s) e das semioses, mas igualmente, dos diversos componentes e constituintes lexicais, morfossintáticos e semânticos específicos de cada idioma. [...] Os estudos da linguagem, considerados (com toda a propriedade) como constituindo algo mais do que a mera descrição de uma língua específica, começaram a focalizar, com maior intensidade, o discurso e as questões culturais e psicossociais das condições de produção do discurso e o receptor enquanto co-autor, conduzindo a Linguística a um ponto de contacto mais próximo com as preocupações da teoria literária. Esta tendência teve um efeito particularmente forte sobre os estudos tradutológicos.
\end{abstract}

$\mathrm{Na}$ atividade científica da tradução ou da interpretação, pode-se pensar em problema de tradução. Problema de tradução, conforme Vasconcellos e Bartholamei (2008), diz respeito a uma representação explícita daquilo que se apresenta como uma situação de tradução de difícil solução. Segundo esses autores, só a partir da estruturação do problema de tradução, será, então, possível fazer uma intervenção consciente para resolvê-lo. Em outras palavras, será possível usar uma estratégia de tradução. Esses autores adotam o conceito de estratégia que consiste em um conjunto de planos potencialmente conscientes para resolver o que, para um indivíduo, se apresenta como um problema na busca por alcançar uma meta comunicativa específica. Nessa definição, salienta-se a natureza individual do problema e a característica consciente de estratégia. Pode-se, então, dizer que uma estratégia é um conjunto de planos potencialmente conscientes para solucionar o que, para um indivíduo, se apresenta como um problema de tradução ou de interpretação. 
A tradução ${ }^{3}$, conforme Aubert (1998), pode ser entendida como qualquer outro ato de comunicação, ou atividade que acontece entre seres humanos e entre grupos sociais, que ocupa lugar entre culturas, ideologias e diferentes visões de mundo. Além disso, a tradução se expressa em sentenças, palavras e orações, que são materializadas em textos e discursos. Vinay \& Darbelnet (1960), por sua vez, explicam que a tradução, operação de transferência de uma língua $\mathrm{X}$ para uma língua $\mathrm{Y}$, com o objetivo de expressar uma mesma realidade, se baseia numa disciplina particular cujo objetivo é evidenciar as características específicas de cada língua. Assim, fundamenta-se sua importância para este estudo.

Aubert (1998) afirma que a tradução consiste numa disciplina que possui técnicas próprias e enfrenta problemas específicos. Para este autor, um conhecimento melhor dos métodos e procedimentos de tradução, assim como a assimilação e a utilização das técnicas específicas, possibilitarão encontrar um número cada vez maior de soluções e, com isto, será possível fazer da tradução uma arte. Ele afirma, também, que o tradutor ${ }^{4}$ precisa saber distinguir o obrigatório do opcional, ou seja, aquilo que a língua impõe pela norma e que deve ser obedecido, e o que é facultativo, que é possível escolher como sendo a melhor opção para traduzir uma determinada mensagem.

Para Aubert, o tradutor parte do significado e, com base nele, efetua todas as operações de transferência dentro do domínio semântico. Para isso, o tradutor necessita de uma unidade que não seja exclusivamente formal, uma vez que ele não trabalha sobre forma, mas sobre pensamento, pois não traduz palavras, e sim ideias e sentimentos. Partindo-se do princípio de que entre línguas existem semelhanças e diferenças, e que suas relações podem contribuir para o desenvolvimento dos povos e, consequentemente das suas culturas, torna-se evidente a importância de estudos sobre tradução e interpretação. 


\title{
1. Modalidades de Tradução: uma adaptação dos Procedimentos de Tradução
}

A partir das considerações acima, o presente trabalho focaliza uma das várias abordagens técnicas possíveis de análise de tradução e pretende contribuir para a teoria e a prática da tradução, mais especificamente em relação à interpretação para a língua de sinais. O estudo baseia-se em Aubert (1998), que realiza uma revisão do modelo denominado Procedimentos Técnicos da Tradução, proposto inicialmente por Vinay e Darbelnet (1960). Tais procedimentos apresentavam como intenção original a construção de uma referência didática no quadro da formação de tradutores. Quaisquer que sejam suas limitações, o referido modelo tornou-se popular entre os pesquisadores brasileiros (AUBERT, 1998).

\begin{abstract}
Esse modelo foi adaptado aos objetivos de um projeto específico, tendo por finalidade a descrição do 'grau de diferenciação' entre o texto original e o texto traduzido [...]. Neste enfoque, o modelo não mais pretendia descrever procedimentos e sim produtos, razão pela qual a designação 'procedimentos de tradução' foi substituída por 'modalidades de tradução'. (AUBERT, 1998, p. 103).
\end{abstract}

Com isso, as Modalidades de Tradução, reformuladas por Aubert (1998), são utilizadas neste trabalho para a geração de dados adaptados especificamente à interpretação em língua de sinais. Porém, cabe ressaltar que, segundo Aubert (1998), o seu modelo "não contém em si qualquer implicação específica sobre a natureza da linguagem e de cada língua, devendo ser entendido simples e diretamente como um entre vários modelos práticos para efetuar uma descrição comparada das estruturas de superfície entre um texto fonte e seu texto meta correspondente" (AUBERT, 1998, p.111). 
O quadro a seguir mostra, respectivamente, as categorias que compõem o modelo de Vinay e Darbelnet e a proposta classificatória de Aubert ${ }^{5}$.

\begin{tabular}{|c|l|c|l|}
\hline \multicolumn{2}{|c|}{ Modelo de Vinay e Darbelnet } & \multicolumn{2}{c|}{ Proposta de Aubert } \\
\hline CÓDIGOS & PROCEDIMENTOS & CÓDIGOS & MODALIDADES \\
& & & \\
01 & Adaptação & 01 & Acréscimo \\
02 & Decalque & 02 & Adaptação \\
03 & Empréstimo & 03 & Correção \\
04 & Equivalência & 04 & Decalque \\
05 & Modulação & 05 & Empréstimo \\
06 & Tradução Literal & 06 & Erro \\
07 & Transposição & 07 & Explicitação / \\
& & 08 & Implicitação \\
& & 09 & Modulação \\
& & 10 & Traduçãão Intersemi- \\
& & 11 & Tradução Literal \\
& & 12 & Transcrição \\
& & 13 & Transposição \\
& & & \\
\hline & & & Modalidades \\
& & Hínbridos &
\end{tabular}

QUADRO 1: Categorias que compõem o modelo de Vinay e Darbelnet e a proposta de Aubert

Em ambas as propostas algumas modalidades podem também ocorrer simultaneamente, dando origem às modalidades híbridas como, por exemplo, a $(12+5)$ transposição com empréstimo; $(12+11)$ a transposição com tradução literal; $(12+7)$ a transposição com explicitação/implicitação e a $(12+2)$ transposição com adaptação. 
Na tabela acima, é possível observar que Aubert elege uma escala de diferenciação que se estende sobre treze pontos e que é representada pelas Modalidades de Tradução. A seguir, cada uma destas modalidades serão descritas com seus respectivos exemplos associados à Libras.

\section{Metodologia}

Conforme já mencionado, este artigo visa discutir a prática da interpretação simultânea da LP para a Libras em relação às Modalidades de Tradução descritas por Aubert (1998). O texto interpretado denomina-se "Descobrindo quem somos nós" e foi extraído do livro "Aprender a ver: o ensino da língua de sinais americana como segunda língua" de autoria de Wilcox e Wilcox (2005). Para auxiliar os intérpretes no processo de interpretação, o referido texto foi narrado oralmente em português, através de leitura fluente, por um profissional experiente da área do jornalismo e gravado previamente em arquivo audiovisual. As interpretações foram coletadas por meio de gravações em vídeos realizadas em estúdio fechado com a aprovação do Comitê Nacional de Ética em Pesquisas com Seres Humanos. Posteriormente, os dados foram analisados por intermédio do software ELAN ${ }^{6}$. Na apresentação dos exemplos dos enunciados da Libras utilizou-se a imagem dos sinais realizados pelos/pelas intérpretes em conjunto com as Glosas ${ }^{7}$ como recurso de registro, facilitando a aproximação do par linguístico, entretanto não perdendo de vista a natureza visual das línguas de sinais, os sinais serão descritos quando necessário.

A fim de ajudar o leitor na compreensão das comparações entre as definições de Aubert (1998) e os exemplos apresentados em Libras, será exposto o Texto Fonte em Língua Portuguesa escrita que serviu de base para a interpretação. 


\section{Descobrindo quem somos "nós"}

Pode-se supor que para os Surdos, assim como para todas as pessoas, existem pelo menos dois tipos de pessoas: "nós" e "eles". As crianças começam a vida assumindo que todos são iguais. As culturas as ensinam a diferenciar-se: algumas pessoas são como nós, mas a maior parte do mundo é diferente. A tarefa da criança, em seu processo de aculturação, é o de descobrir quem somos "nós" e quem são "eles".

Para a criança Surda, a tarefa não é diferente. Em um livro maravilhoso sobre cultura Surda, chamado "Os Surdos na América", dois pesquisadores Surdos americanos contam a história de como uma criança Surda adquiriu esse senso de "nós" e "eles". Essa criança é Sam Supalla, hoje um renomado educador Surdo e pesquisador universitário das línguas de sinais.

Sam nasceu em uma família de Surdos com vários irmãos Surdos mais velhos. Conforme seus interesses se voltavam para o mundo fora de sua família, ele conheceu uma garota que vivia ao lado de sua casa e que parecia ser da sua idade. Depois de alguns encontros, eles se tornaram amigos. Ela era uma companheira agradável, mas havia o problema da sua "estranheza". Ele não podia falar com ela da mesma forma que falava com seus irmãos e seus pais. Ela parecia ter uma dificuldade extrema de compreender até mesmo os gestos mais elementares.

Após umas poucas tentativas frustradas de conversa, ele desistiu e passou a usar gestos e apontamentos quando queria dizer algo ou ir a algum lugar. Ele ficou curioso sobre essa enfermidade estranha que a amiga tinha, mas uma vez que eles haviam encontrado uma forma de interagir, ele contentou-se em se acomodar às necessidades peculiares da garota. Um dia, Sam lembra-se claramente, ele finalmente compreendeu que sua amiga era de fato excêntrica. Eles estavam brincando na casa dela, quando de repente sua mãe chegou até eles e começou a mover sua boca animadamente. Como que num passe de mágicas, a garota pegou seus brinquedos e os levou para outro lugar. Sam ficou intrigado e voltou para casa para perguntar a sua mãe de que mal, exatamente, a sua amiga vizinha sofria. Sua mãe explicou que ela era "ouvinte" e, por esse motivo, não sabia sinalizar; ao invés disso, ela e sua mãe "falavam", movendo suas bocas para se comunicarem. Sam então perguntou se essa garota e sua família eram as únicas pessoas "desse tipo".

Sua mãe explicou que não, na verdade, quase todos eram como seus vizinhos. Sua própria família que era incomum. Foi um momento 
memorável para Sam. Ele lembra-se de ter pensado como era esquisita a garota ao lado e, se ela era "ouvinte", como as pessoas "ouvintes" deviam ser esquisitas também.

Conforme crianças Surdas como Sam vão se tornando adultas, elas aprendem valores culturais Surdos de outros membros da comunidade. E o universo Surdo é um universo em si bastante complexo, habitado por muito mais categorias do que as mencionadas aqui. Além de "surdos" e "ouvintes", há também os "deficientes auditivos", que caminham sobre uma linha que divide o mundo Surdo do mundo ouvinte. Há também pessoas "oralizadas", que abraçam o mundo ouvinte e se enxergam como ouvintes, não apresentando uma identificação direta com Surdos usuários de língua de sinais.

A visão sobre "surdez", sobre quem somos "nós” e quem são "eles", portanto, vai depender das experiências compartilhadas por cada pessoa Surda ao longo de seu desenvolvimento. Embora o fator biológico, o fato de não ouvir, seja um aspecto relevante, ele certamente não pode ser tomado como critério único da definição de "ser Surdo", tampouco como o critério para se definir quem se reconhece como pertencente à cultura e à comunidade Surda.

QUADRO 2 - Texto extraído do livro "Aprender a ver" Fonte: Wilcox; Wilcox (2005, p. 104-106)

\section{Modalidades de Tradução na Libras: análise e discussão}

A seguir, serão analisadas e discutidas cada uma das referidas modalidades com seus respectivos exemplos em Libras visualizados por meio de imagens extraídas do programa ELAN.

A Modalidade de Tradução denominada Acréscimo é frequentemente utilizada pelos tradutores a fim de acrescentar e complementar as informações emitidas no Texto Alvo (TA)

Trata-se de qualquer segmento textual incluído no texto alvo pelo tradutor por sua própria conta, ou seja, não motivado por qualquer conteúdo explícito ou implícito do texto original. 
O acréscimo não deve ser confundido com qualquer das formas de transposição, nem com a explicitação. Acréscimos podem ocorrer em várias circunstâncias distintas, por exemplo, na forma de comentários velados ou explícitos do tradutor, quando fatos que tenham ocorrido após a produção do texto fonte justifiquem a elucidação. (AUBERT, 1998, p. 109-110).

A sequência das imagens apresentadas abaixo ilustra o momento em que o uso dessa modalidade ocorre. Logo no início da sua interpretação, antes de começar o texto propriamente dito, a intérprete faz uso da Modalidade de Tradução denominada Acréscimo para a contextualização do texto que será interpretado. Ou seja, antes de interpretar o título do texto ela contextualiza ao público, introduzindo os sinais TEMA LÍNGUA-DE-SINAIS, informando que o tema será sobre a língua de sinais, sendo que este comentário não se encontra na narração do texto original. A intérprete em questão fez a leitura da sinopse do referido texto previamente a sua interpretação, sendo que este procedimento forneceu o acesso à referida informação e, consequentemente, pode ter contribuído para a realização do esclarecimento ao público alvo.

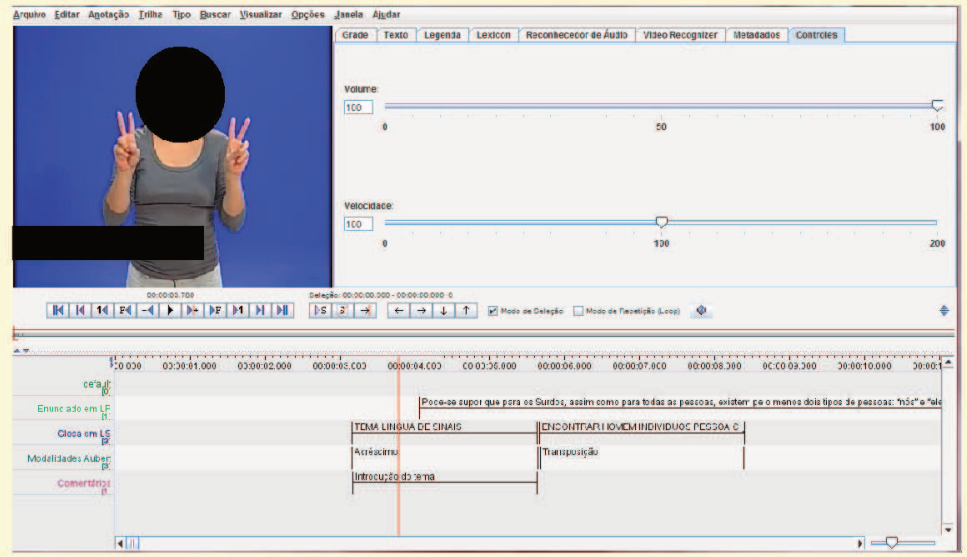

FIGURA 1 - Modalidade de Tradução: Acréscimo - Imagem como o uso do ELAN Fonte: Nicoloso (2015, p. 65) 


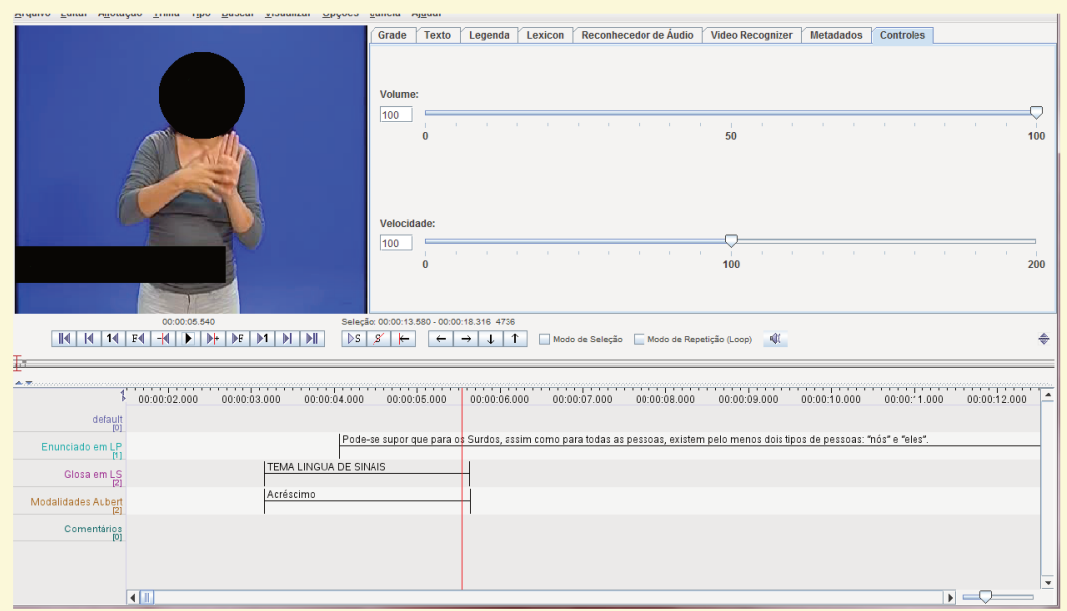

FIGURA 2 - Modalidade de Tradução: Acréscimo

Fonte: Nicoloso (2015, p. 65)

O uso de Adaptação, por sua vez, ocorre com a finalidade de estabelecer uma aproximação com a língua e cultura de chegada, para que o texto seja confortável na sua recepção.

Esta modalidade denota uma assimilação cultural; ou seja, a solução tradutória adotada para o segmento textual dado estabelece uma equivalência parcial de sentido, tida por suficiente para os fins do ato tradutório em questão, mediante uma intersecção de traços pertinentes de sentido, mas abandona qualquer ilusão de equivalência 'perfeita'. (AUBERT, 1998, p. 108).

No exemplo em Libras, a solução tradutória adotada pelo intérprete para a interpretação do seguimento textual "Descobrindo quem somos nós" é a utilização da Adaptação como Modalidade de Tradução, pois há uma assimilação cultural para satisfazer uma "equivalência parcial de sentido". Ou seja, o intérprete faz uso da palavra SINAL, que pertence ao léxico da Libras com a função de 
determinar ou identificar alguém ou alguma coisa, para representar o sentido imposto no Texto Fonte pelo léxico "quem somos nós" / "indivíduos".

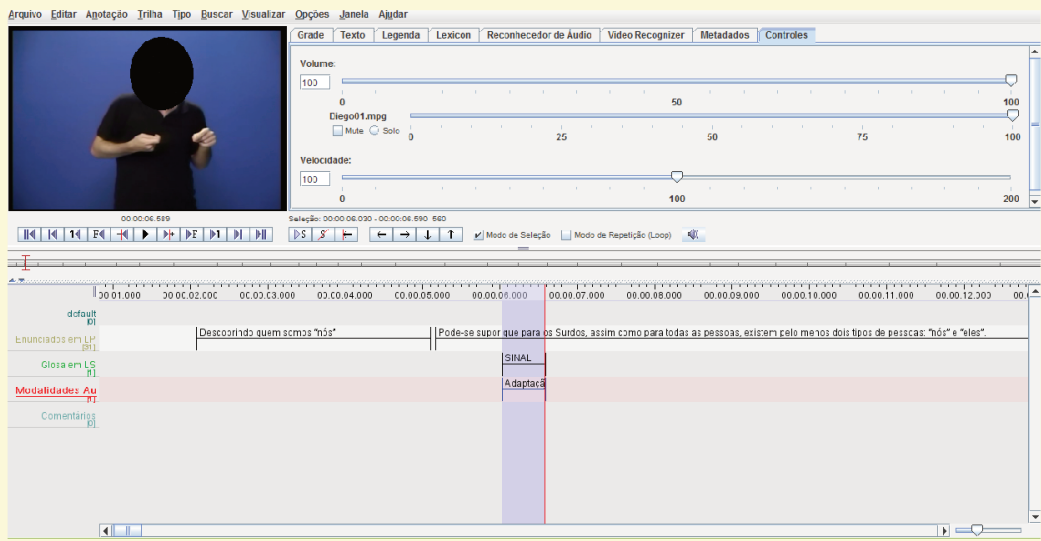

FIGURA 3 - Modalidade de Tradução: Adaptação

Fonte: Nicoloso (2015, p. 66)

Os textos, com certa frequência, "contém erros factuais e/ou linguísticos, inadequações e gafes. Se o tradutor optar por 'melhorar' o texto meta em comparação com o texto fonte, considerarse-á ter ocorrido uma Correção" (AUBERT, 1998, p.109). O texto interpretado em Libras, da mesma forma, poderá conter Correção quando o/a intérprete optar por organizar melhor um enunciado em português, ou consertar algum equívoco cometido pelo orador. No entanto, os dados apresentados neste artigo foram coletados a partir de um Texto Fonte (TF) pronto, previamente selecionado e cuidadosamente elaborado, portanto não apresentou erros e/ou equívocos de quaisquer natureza para que fossem corrigidos pelos/ pelas intérpretes.

Contudo, no texto em Libras, a Correção também poderá ocorrer quando o próprio intérprete comete um equívoco e faz a alteração no seu próprio texto, ou seja, uma autocorreção. Interessante apontar que em uma tradução, na maioria dos casos, a autocorreção 
praticamente não aparece, pois ocorre antes do texto chegar aos olhos do público. O fator tempo contribui para que as autocorreções possam ser realizadas no momento da elaboração da tradução, na sua revisão, na sua edição e antes da publicação do texto final. Em contrapartida, na interpretação simultânea o fator tempo é um agravante para que correções aconteçam com maior frequência e sejam percebidas pelo público alvo (NICOLOSO, 2015).

A sequência das imagens apresentadas a seguir ilustra a ocorrência da Modalidade de Tradução denominada Correção, mais precisamente de uma autocorreção, na interpretação do seguimento textual: "Os surdos na América". Ao fazer o sinal da palavra CULTURA, a intérprete percebe que o sinal correto que deve ser empregado no contexto da frase é o sinal de SURDO, então, rapidamente, realiza a alteração/correção do mesmo, ou seja, ela corrige o sinal de CULTURA substituindo-o pelo sinal de SURD@/ SURDEZ.

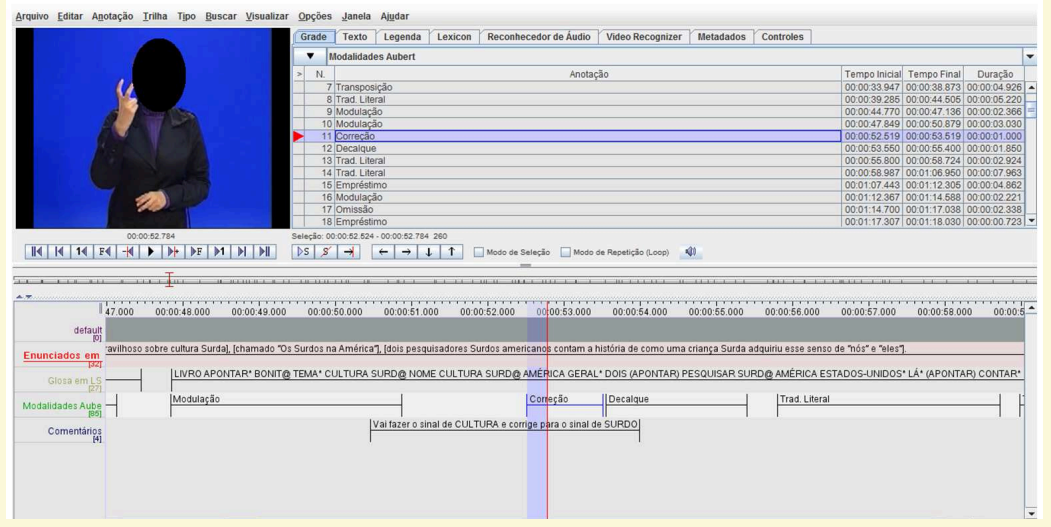

FIGURA 4 - Modalidade de Tradução: Correção

Fonte: Nicoloso (2015, p. 67) 


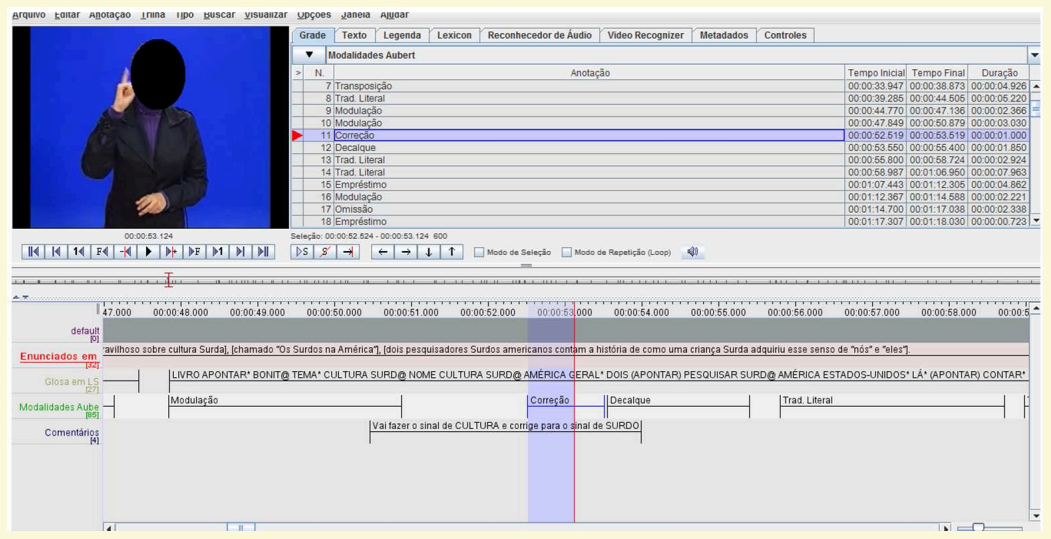

FIGURA 5 - Modalidade de Tradução: Correção

Fonte: Nicoloso (2015, p. 67)

Além das imagens de interpretação da intérprete nas Figuras 4 e 5, pode-se observar a identificação da modalidade Correção, na parte superior dos quadros acima (ao lado das imagens da intérprete) e no centro da parte inferior.

Outra modalidade, para Aubert (1998), o Decalque refere-se a "uma palavra ou expressão emprestada da Língua Fonte, mas que (i) foi submetida a certas restrições ou adaptações gráficas e/ou morfológicas para conformar-se às convenções da Língua Alvo; e que (ii) não se encontra registrada nos principais dicionários recentes da Língua Fonte" (AUBERT, 1998, p. 106).

O exemplo em Libras, ilustrado nas imagens a seguir, apresenta o momento em que a intérprete utiliza o Decalque para interpretar a expressão "deficientes auditivos", ou seja, sua decisão tradutória é a de restrições fonológicas e morfológicas, sofridas pelo empréstimo linguístico, suprimindo o referido termo por meio do uso do alfabeto manual das letras D e A para a abreviação da expressão. Embora o termo [D-A] faça parte do léxico da Libras em determinados contextos, ele ainda não se encontra nos principais dicionários dessa língua. 


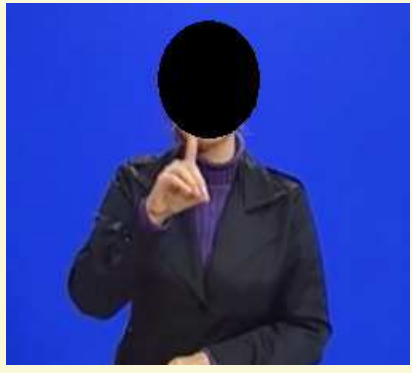

FIGURA 6 - Modalidade de Tradução: Decalque

Fonte: Nicoloso (2015, p. 68)

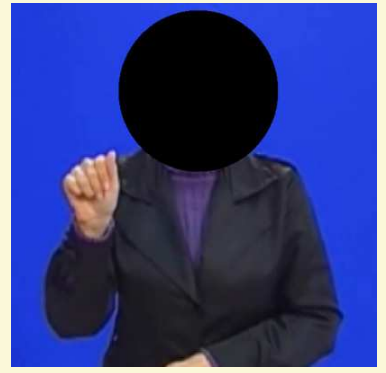

FIGURA 7 - Modalidade de Tradução: Decalque

Fonte: Nicoloso (2015, p. 69)

A modalidade Empréstimo "é um segmento textual do Texto Fonte reproduzido no Texto Meta". Aubert (1998, p. 106) explica que "nomes próprios constituem objetos privilegiados de empréstimo, bem como termos e expressões tendo por referentes realidades antropológicas e/ou etnológicas específicas”. Sendo assim, “a tradução de uma palavra que não tem, na língua de tradução, um significante com o mesmo significado com que é empregada no texto de origem pode ser feita por meio de um empréstimo" (BASTIANETTO, 2012, p. 6). Barbosa (1990) afirma que tal estratégia é considerada a mais simples pelo fato de que ela é meramente uma cópia da língua de origem para a língua de chegada. De acordo com Branco (2011, p.239) "embora os estudiosos da tradução utilizem denominações distintas para diferentes estratégias, eles são unânimes ao declarar que a mais simples de todas as estratégias é o empréstimo linguístico". Aubert (1994) afirma que em alguns casos específicos é comum que uma "cultura periférica" absorva as informações, dados e conceitos da "cultura central". O uso de empréstimos linguísticos é, no ponto de vista de Aubert, uma solução apropriada.

No exemplo a seguir o intérprete faz uso do Empréstimo utilizando o alfabeto manual para interpretar o nome próprio "Sam Supalla”. Nas línguas de sinais, frequentemente, os empréstimos linguísticos ocorrem por meio da dactilologia, ou seja, por meio do 
uso de "um conjunto de configurações de mão que representam o alfabeto português” (QUADROS; KARNOPP, 2004, p.88)

\begin{abstract}
A maioria dos empréstimos linguísticos que entram na língua de sinais advém de uma língua oral. Essa importação tem uma peculiaridade na adequação fonológica, porque o empréstimo de uma língua oral para uma língua tipicamente de sinais ocorre, principalmente, a partir da escrita da língua de modalidade oral-auditiva para essa de modalidade espaço-visual. Por tratar-se de modalidades diferentes, as palavras importadas de uma língua oral apresentam especificidades ao entrarem nas línguas de sinais, na forma de datilologia. (NASCIMENTO, 2010, p. 27).
\end{abstract}

As figuras abaixo ilustram o momento em que o intérprete realiza a ação de soletração do referido nome próprio S-A-M S-U-P -A-L-L-A.

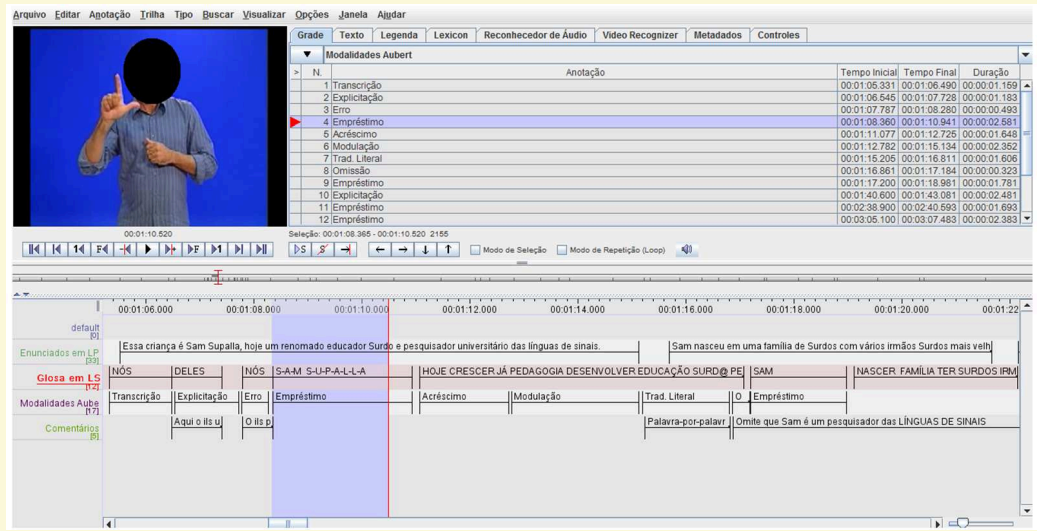

FIGURA 8 - Modalidade de Tradução: Empréstimo

Fonte: Nicoloso (2015, p. 70) 


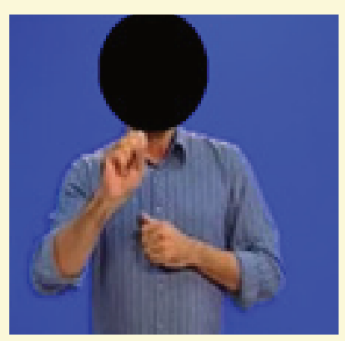

S

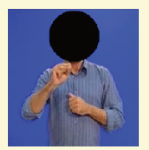

S

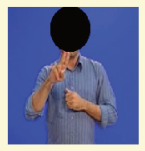

$\mathrm{U}$

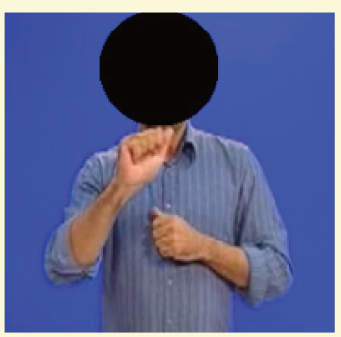

A

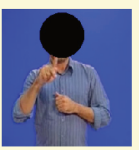

$\mathrm{P}$

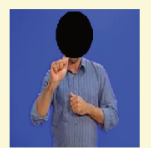

A
$\mathrm{L}$

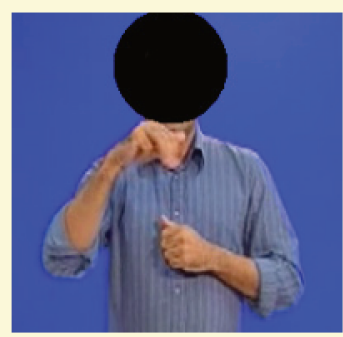

M

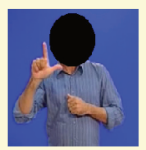

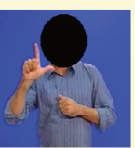

$\mathrm{L}$

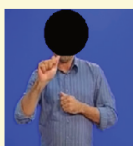

A

Para Aubert (1998), deve ser considerado Erro, por sua vez, os casos perceptíveis de distorção do sentido a ponto de comprometer o contexto e a inteligibilidade do discurso.

somente os casos evidentes de 'gato por lebre' incluem-se nesta modalidade. Esta categoria não abarca, portanto, as soluções tradutórias percebidas como 'inadequadas', estilisticamente inconsistentes, etc., visto que, em tais casos, torna-se inevitável um viés subjetivo, que poderia redundar em fortes distorções nos resultados finais. (AUBERT, 1998, p. 109).

Para interpretar o título do livro "Os Surdos na América” a intérprete utiliza a sequência dos sinais HISTÓRIA DENTRO AMÉRICA evidenciando um Erro. Esta modalidade é identificada quando o sentido da mensagem enunciada pelo narrador encontrase equivocado ao sentido reproduzido na informação transmitida pela intérprete. Ou seja, o título do livro fala sobre "os surdos" na América. No entanto, a informação repassada apresenta a ideia 
de que o título do livro trata-se da "história" na América. Portanto, surdo e história são duas categorias diferentes para efeito da interpretação esperada, comprometendo a mensagem transmitida no Texto Alvo em relação à mensagem desejada pelo Texto Fonte.

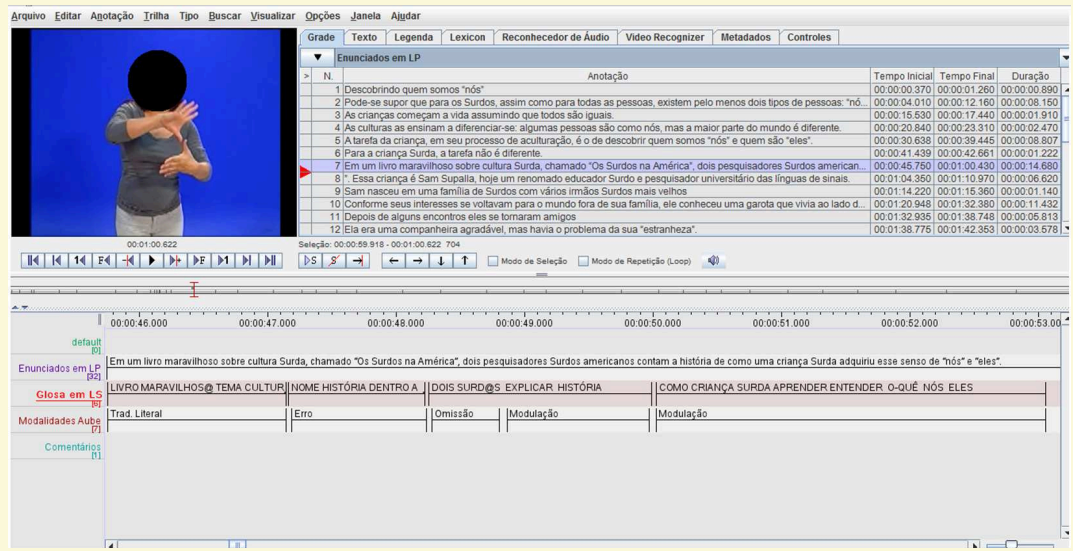

FIGURA 9 - Modalidade de Tradução: Erro

Fonte: Nicoloso (2015, p. 71)

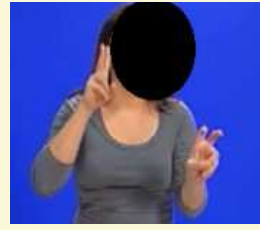

HISTÓRIA

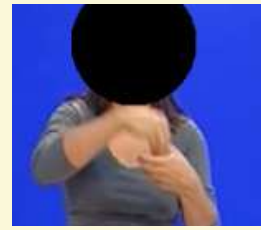

DENTRO

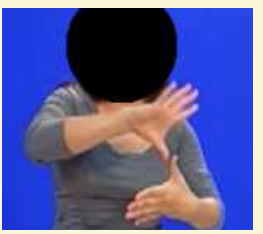

AMÉRICA

No caso de Explicitação/Implicitação, o uso destas modalidades é bastante frequente e embora elas sejam essencialmente opostas, Aubert (1998) as coloca em uma mesma classificação. Segundo o autor, elas "são consideradas duas faces da mesma moeda, em que informações implícitas contidas no texto fonte se tornam explícitas no texto meta ou, ao contrário, informações explícitas contidas no 
texto fonte e identificáveis com determinado segmento textual, tornam-se referências implícitas" (AUBERT, 1998, p. 107).

Apesar de Aubert (1998) considerar estas duas Modalidades de Tradução (Explicitação e Implicitação) como "duas faces da mesma moeda", classificando-as em uma mesma categoria analítica, neste estudo elas foram analisadas separadamente.

Dessa forma, a figura apresentada abaixo ilustra o momento em que o intérprete realiza uma Explicitação para a interpretação do trecho narrado em português: [...] existem pelo menos dois tipos de pessoas: 'nós' $e$ 'eles'. Para evidenciar que os surdos pertencem a um dos dois grupos diferenciados no texto, o ILS explicita que dentre o grupo "nós" e o grupo "eles", os surdos fazem parte do grupo "eles". Ou seja, após sinalizar NÓS ELES/DELES o intérprete acrescenta o sinal SURDO para se referir a "eles".

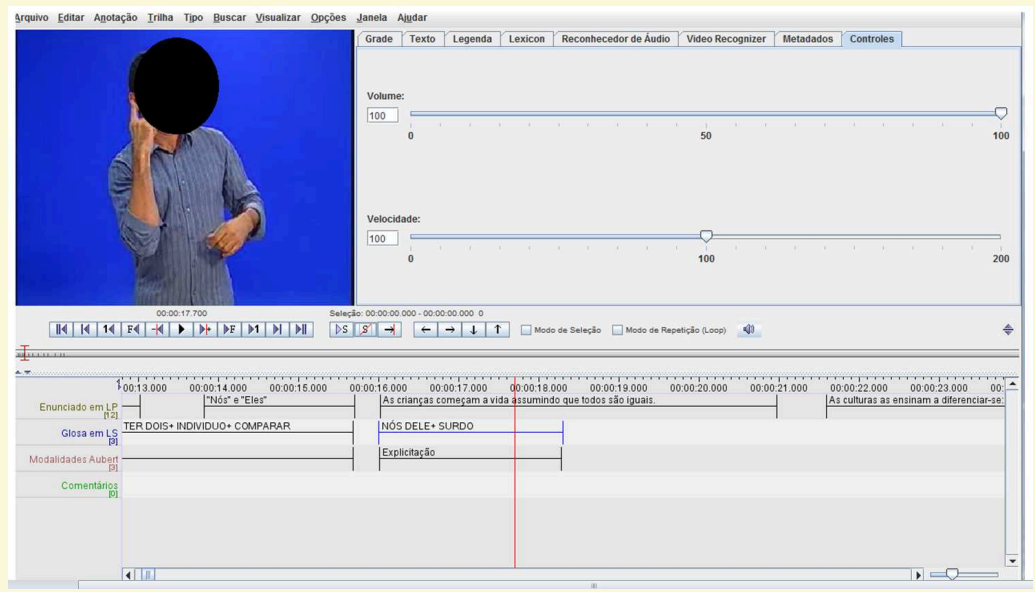

FIGURA 10 - Modalidade de Tradução: Explicitação

Fonte: Nicoloso (2015, p. 72)

Já a figura a seguir ilustra o momento em que o intérprete realiza uma Implicitação. Ao interpretar o trecho do texto: "As culturas as ensinam a diferenciar-se: algumas pessoas são como nós, mas a maior parte do mundo é diferente", a ideia de maioria, a qual está 
explicita no texto em Língua Portuguesa, encontra-se implícita no texto em Libras, sendo que para a interpretação do referido trecho, o intérprete em questão faz uso dos respectivos sinais "CULTURA ENSINAR DIFERENTE ALGUNS PESSOAS IGUAL NÓS MAS AVISAR TER DIFERENÇA" . No quadro do ELAN, a identificação de Implicitação encontra-se marcada na parte inferior.

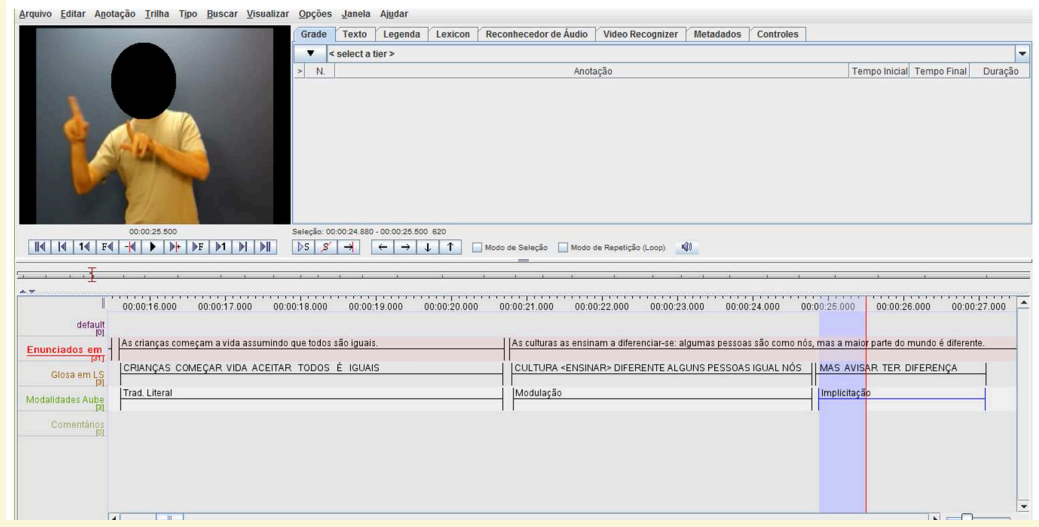

FIGURA 11 - Modalidade de Tradução: Implicitação

Fonte: Nicoloso (2015, p. 72)

A Modulação, por sua vez, é utilizada constantemente nas traduções entre pares de línguas orais. Nas interpretações entre línguas de modalidades diferentes, como é o caso do português e da Libras, também pode-se observar frequentemente o uso de $\mathrm{Mo}$ dulação. Esta Modalidade de Tradução "refere-se às alterações semânticas ou estilísticas mais ou menos profundas, embora mantenha a identidade quanto à situação" (CAMARGO, 1996).

Ocorre modulação sempre que um determinado segmento textual for traduzido de modo a impor um deslocamento perceptível na estrutura semântica de superfície, embora retenha o mesmo efeito geral de sentido no contexto específico. Ou seja, os significados são parcial ou totalmente distintos, 
mas mantém-se, em termos genéricos, o mesmo sentido. A modulação pode assumir formas bastante diversas, desde variações de detalhes, até uma diferenciação tal que nada nas respectivas estruturas de superfície do segmento em questão lembraria ao observador a sua efetiva equivalência tradutória, que somente pode ser recuperada considerandose o sentido contextual. (AUBERT, 1998. p. 108).

A figura apresentada abaixo ilustra o momento em que a intérprete realiza uma Modulação, pois para interpretar o segmento textual "Para a criança surda, a tarefa não é diferente" ela faz uso dos respectivos sinais da Libras: CRIANÇA SURDA IGUAL. Ou seja, ela realiza um deslocamento perceptível na escolha da estrutura semântica dos itens lexicais quando analisados separadamente, sendo que utiliza palavras semanticamente opostas [diferente e igual], mas no contexto específico não modifica o sentido desejado nas sentenças. Assim, pode-se considerar que as sentenças "para a criança surda, a tarefa não é diferente" e "para a criança surda é igual" apresentam a mesma "equivalência semântica" na tradução.

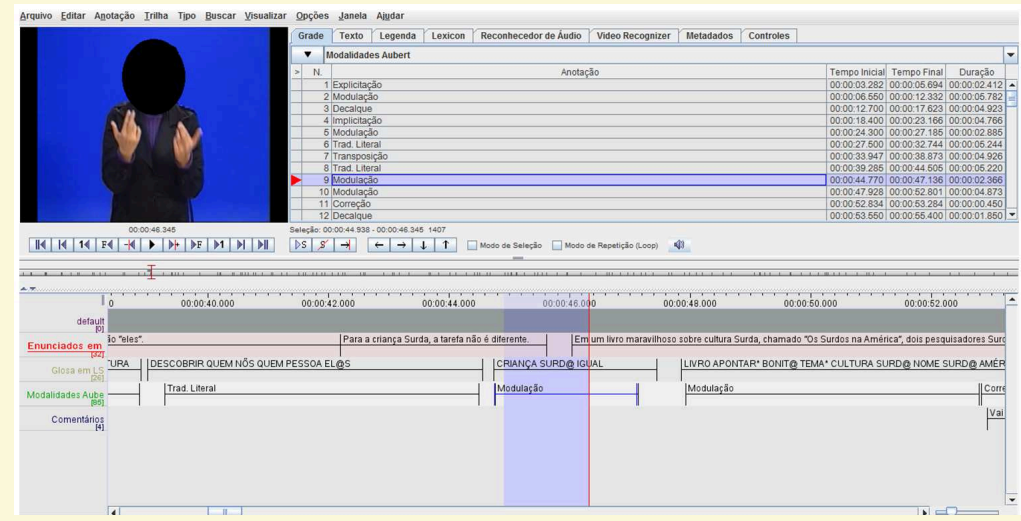

FIGURA 12 - Modalidade de Tradução: Modulação

Fonte: Nicoloso (2015, p. 73) 
Quanto ao uso da modalidade Omissão vários fatores podem contribuir para que essa modalidade ocorra durante uma interpretação simultânea, principalmente quando ela envolve um par linguístico de duas línguas de modalidades diferentes como é o caso das línguas orais e sinalizadas. De acordo com Barbosa (2014, p.8) “as omissões são ocasionadas por demandas durante o processo interpretativo e, em muitos casos, fogem do controle do ILS”.

Ocorre omissão sempre que um dado segmento textual do Texto Fonte e a informação nele contida não podem ser recuperados no Texto Meta. Essa ressalva é de fundamental importância, pois, em inúmeros casos, embora a correspondência biunívoca seja perdida, a informação como tal é perfeitamente recuperável no Texto Meta, como nas transposições e nas implicitações (vide abaixo). As omissões podem ocorrer por muitos motivos, desde censura até limitações físicas de espaço [tempo], irrelevância do segmento textual em questão para os fins do ato tradutório específico, fins que nem sempre coincidem com os propósitos do ato de comunicação que gerou o Texto Fonte. (AUBERT, 1998, p. 105).

No exemplo em Libras apresentado a seguir, especificamente no trecho do texto narrado oralmente: "[...] dois pesquisadores surdos americanos contam a história [...]”, aparece uma Omissão quando a intérprete não contempla em sua interpretação em Libras a informação sobre o fato de o livro ter sido escrito por dois "pesquisadores americanos". Para a interpretação do referido trecho ela faz uso dos respectivos sinais da Libras: DOIS SURD@ O-QUE EXPLICAR HISTÓRIA, conforme ilustra a figura a seguir na descrição em glosas. 


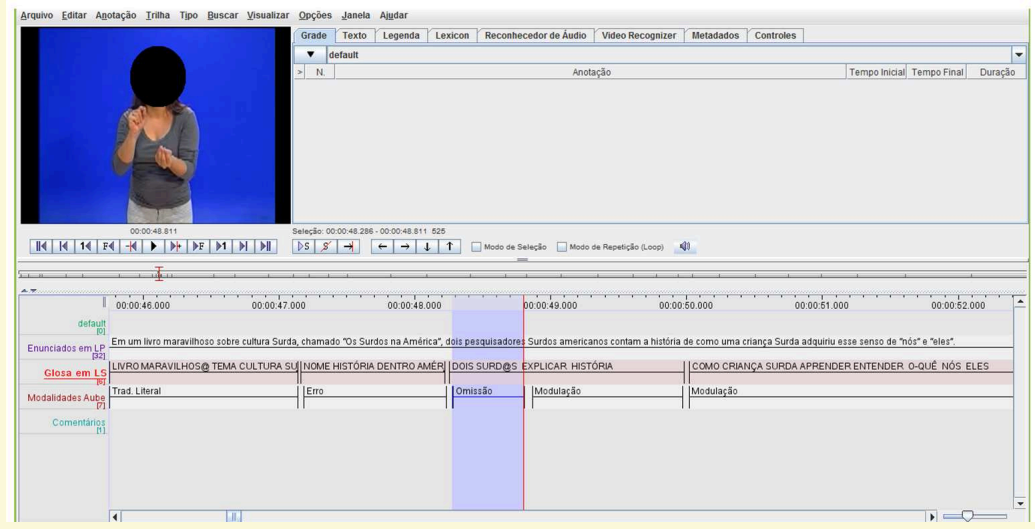

FIGURA 13 - Modalidade de Tradução: Omissão

Fonte: Nicoloso (2015, p. 74)

Quanto à Tradução literal, esta modalidade acontece com frequência nas interpretações simultâneas e observa-se que os intérpretes fazem uso da Tradução Literal nos mais variados textos e contextos. O conceito de Tradução Literal, conforme Aubert (1998, p. 106):

é sinônimo de tradução palavra-por-palavra e em que, comparando-se os segmentos textuais fonte e alvo, se observa (i) o mesmo número de palavras, (ii) na mesma ordem sintática, (iii) empregando as mesmas categorias gramaticais e (iv) contendo as opções lexicais que, no contexto específico, podem ser vistas como sinônimos interlinguísticos.

No entanto, a tradução "palavra-por-palavra” é caracterizada, segundo a definição de Aubert (1998), como a tradução em que determinado segmento textual (palavra, frase, oração) é expresso na língua alvo mantendo-se as mesmas categorias numa mesma ordem sintática, utilizando vocábulos em que a semântica seja aproximadamente idêntica ao dos vocábulos correspondentes na 
língua fonte. Dessa forma, uma tradução palavra-por-palavra da LP para a Libras, conforme Santiago (2012) pode corresponder ao "português-sinalizado", que na maioria das situações pode ser considerado inadequado às necessidades e peculiaridades do discurso na língua de sinais, considerando o efeito de sentido necessário. Para Sobral (2008 apud SANTIAGO, 2012, p. 40) "é preciso desenvolver a capacidade de ser fiel ao enunciado original sem violar a língua para qual se traduz, o português sinalizado 'improvisa' sentidos, enquanto a LIBRAS 'cria' sentidos" (SOBRAL, 2008, p. 11).

Sobral (2008, p. 40) explica que "as línguas são traduzíveis, ou seja, postas em correspondência, mas não tradutíveis, ou seja, postas em equivalência" e para ele, "há nas línguas um conjunto de possibilidades de produção de sentido". É importante reconhecer que aproximar duas línguas de estruturas diferentes não é uma tarefa fácil, pois nas línguas de sinais estão presentes diferentes elementos linguísticos como os aspectos não manuais (direção do olhar, expressão facial, deslocamento de sobrancelhas, movimentos corpóreos) e a incorporação do sujeito que não se apresentam da mesma forma na modalidade oral-auditiva a ponto de possibilitar uma perfeita aproximação. As expressões faciais e corporais, conforme Felipe (2007), podem complementar os itens lexicais estabelecendo melhor o contexto.

No procedimento de Tradução Literal, segundo Santiago (2012, p. 41), "a sintaxe pode ser alterada de acordo com as normas gramaticais da língua de tradução". Assim, a tradução "palavra por palavra" segue a mesma ordem sintática, enquanto que na Tradução Literal poderá haver uma adequação morfossintática. Em determinados contextos, porém, pode-se observar que uma Tradução Literal do português para a Libras também é considerada uma Tradução "palavra-por-palavra" conforme o exemplo a seguir. 


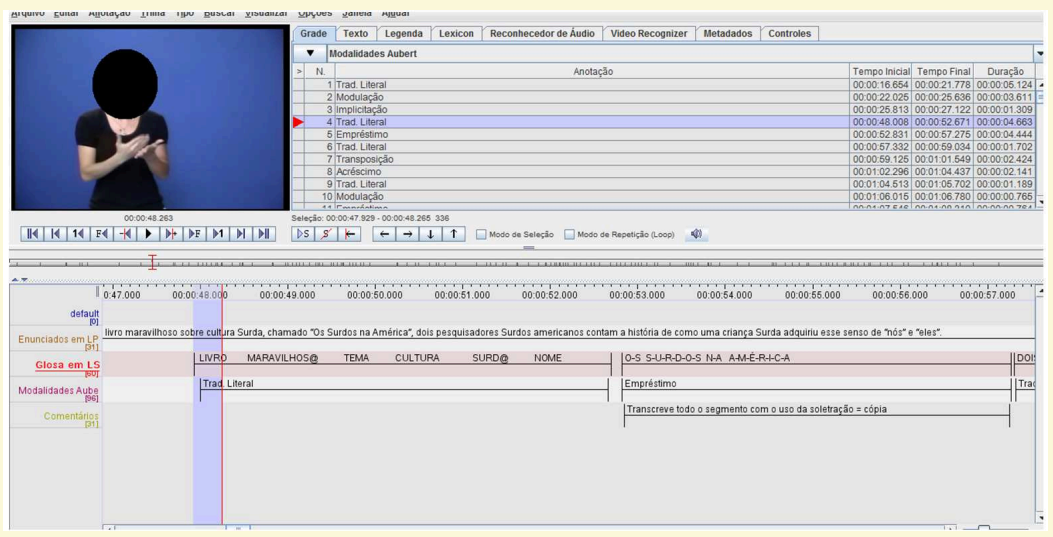

FIGURA 14 - Modalidade de Tradução Literal

Fonte: Nicoloso (2015, p. 75)

Na figura acima a intérprete faz uma Tradução Literal e palavra-por-palavra para interpretar o trecho narrado em português: "livro maravilhoso sobre cultura Surda", sendo que utiliza sequencialmente os sinais da Libras: LIVRO MARAVILHOS@ TEMA CULTURA SURD@, que no contexto específico e na percepção linguística das línguas de sinais está congruente com a sequência gramatical, sintática e lexical da Língua Portuguesa, podendo ser entendidas como "sinônimos interlinguísticos". Sendo assim, estão presentes os critérios descritos por Aubert (1998) para definir essa Modalidade de Tradução.

De acordo com Santiago (2012, p. 40), “aproximar o enunciado da tradução da estrutura linguístico-enunciativa da língua alvo faz os sentidos emergirem de forma natural". Portanto, o exemplo a seguir ilustra outra possibilidade de Tradução Literal onde a sintaxe é modificada de acordo com as normas gramaticais da libras. Para a interpretação do enunciado Os surdos na América, foram utilizados os respectivos sinais AMÉRICA SURD@AQUI (aponta para a mão aberta). Nesta tradução se observa um exemplo de Topicalização na Libras. Para Santiago (2012, p. 41) “este é um recurso linguístico que pode ser identificado nos procedimentos 
de Tradução Literal”. No exemplo citado, os termos utilizados nas duas línguas são praticamente os mesmos, entretanto a estrutura sintática foi alterada, mantendo a semântica. Na sentença em Libras, o objeto direto (AMÉRICA) é o tópico da sentença. Isso não significa que, conforme Santiago (2012, p. 41), "sempre que a topicalização estiver presente em uma sentença interpretada para Libras, que se trata de tradução literal”.

Português: "Os surdos na América"

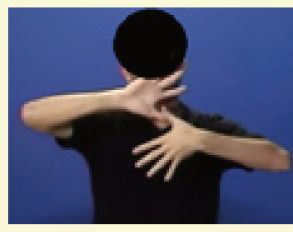

Libras:

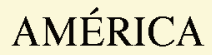

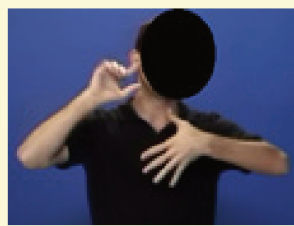

SURD@

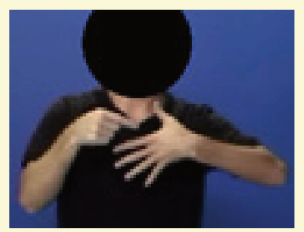

AQUI

A Tradução intersemiótica, no entanto, ocorre quando "em determinados casos, particularmente na tradução dita 'juramentada', figuras, ilustrações, logomarcas, selos, brasões e similares [icônicos] constantes do texto fonte vêm reproduzidos no texto alvo como material textual" (AUBERT, 1998, p. 109). No caso específico das línguas de sinais a pesquisa de Segala (2010) pode contribuir com este trabalho, pois enfatiza que quando a Libras entra como uma das línguas no processo tradutório, sempre é possível se deparar com uma tradução intersemiótica. Cenários construídos, representações de ações e, até mesmo, certos Classificadores (CL) podem pertencer a esta categoria de Modalidade de Tradução pelo fato de serem essencialmente icônicos

A tradução realizada em um espaço que parte de um texto escrito em Português acadêmico para uma Língua de Sinais exige uma tradução visual, ou seja, a tradução é gravada pelo tradutor/ator/coautor que também desempenha o papel 
de ator [personagens e cenários] dessa tradução. Ele usa não só sua capacidade de traduzir e de compreender o texto, mas também expõe sua imagem para registrar em vídeo o produto final. Por isso a tradução que se faz nesse espaço é intersemiótica, além de ser interlinguística. (SEGALA, 2010, p.8).

Segala também acrescenta que

A tradução de Língua Portuguesa escrita, como línguafonte, para a Libras, como língua-alvo, não pode considerar apenas a tradução intermodal, devido ao fato de que, para essa tradução, há a necessidade da imagem [da performance, da incorporação do sujeito, da iconicidade, do uso do espaço, de classificadores]. Nesse sentido, é feita uma tradução da língua escrita [ou oral] para sinais, através da tradução intersemiótica. (SEGALA, 2010, p. 28).

A partir da análise deste autor, pode-se compreender que o presente artigo refere-se à interpretação intermodal e interlingual, por se tratar da interpretação entre duas línguas de modalidades distintas (oral/escrita e gestual), assim como de signos verbais/escritos do português e descrições imagéticas da Libras. Entretanto, o conceito de descrições imagéticas, segundo Luchi (2013, p. 55),

coloca em dúvida se estamos trabalhando com uma interpretação interlingual ou intersemiótica, ou se são as duas ao mesmo tempo. Interlingual por se tratar de duas línguas e intersemiótica por se tratar da construção sinalizada de imagens altamente icônicas que podem fazer intersecção a outro sistema de linguagem presente, talvez, em apenas línguas sinalizadas. 
Conforme esse autor, sendo as descrições imagéticas parte da língua de sinais pode-se falar, portanto, de interpretação interlinguística também. Assim, pode-se reconhecer que a/o intérprete ao sinalizar uma descrição imagética ou representar uma ação de forma teatralizada estará fazendo uma interpretação intersemiótica e intralingual, pois o mesmo transmuta elementos da linguagem imagética e icônica para a língua de sinais. Veja o exemplo em Libras a seguir.

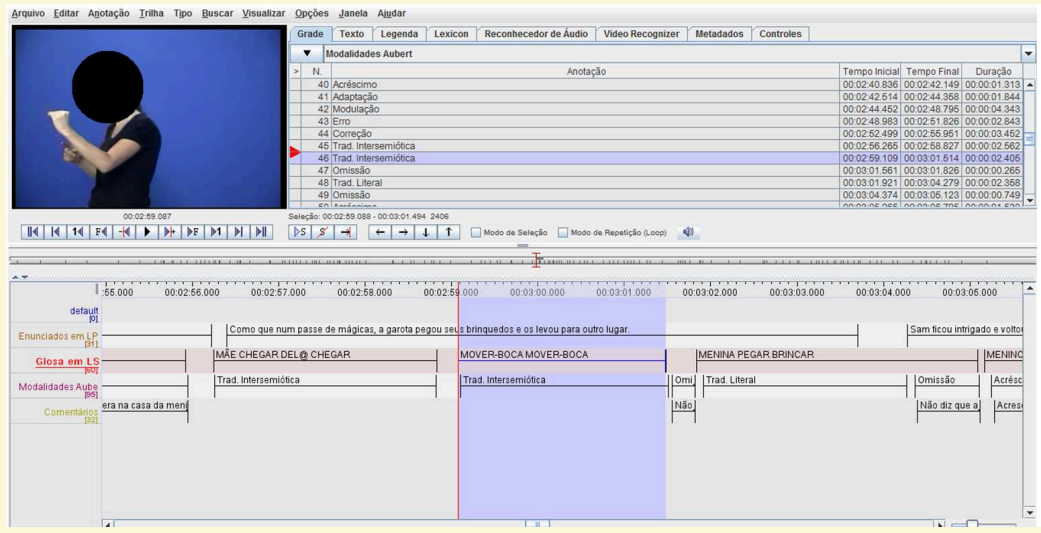

FIGURA 16 - Modalidade de Tradução: Tradução Intersemiótica Fonte: Nicoloso, 2015, p. 152

A imagem acima apresenta o uso da Tradução Intersemiótica para a interpretação do trecho grifado do texto em Língua Portuguesa: "Eles estavam brincando na casa dela, quando de repente sua mãe chegou até eles e começou a mover sua boca animadamente”. A intérprete faz a identificação do sujeito no cenário construído para representar a descrição da imagem da ação teatralizada da mãe de mover a boca para falar, mexendo a mão dominante próximo à região lateral da boca situando através do espaço sua respectiva localização no cenário construído. $\mathrm{O}$ ato de "mover a boca animadamente" é texto e ao ser representado pela intérprete de maneira "teatralizada" caracteriza uma Tradução Intersemiótica. 
Quanto à Transcrição, ela é a manutenção de uma palavra ou sinal em Libras mencionado no texto narrado em português. Portanto, o uso desta modalidade é percebido nas interpretações em Libras quando os termos (itens lexicais) pertencem à Libras e são pronunciados nos discursos produzidos na Língua Portuguesa oral ou escrita; ou quando são termos de origem em uma terceira língua fora do par linguístico envolvido na interpretação e que possam causar dúvidas relacionadas ao seu verdadeiro efeito semântico. Sendo assim, a Transcrição pode ser a resolução de um problema de tradução, pois evidencia o termo e o significado esperado para um determinado conceito no contexto desejado.

Este é o verdadeiro 'Grau Zero' da tradução. Inclui segmentos de texto que pertençam ao acervo de ambas as línguas envolvidas ou, ao contrário, que não pertençam nem à língua fonte nem à língua alvo, e sim a uma terceira língua e que, na maioria dos casos, seriam considerados empréstimos no texto fonte. Ocorre, ainda, transcrição sempre que o Texto Fonte contiver uma palavra ou expressão emprestada na Língua Alvo. (AUBERT, 1998, p. 106).

É importante esclarecer que o texto supracitado, utilizado neste artigo, não apresentou Transcrição em sua interpretação. No entanto, utilizou-se um exemplo coletado de outro texto para exemplificar sua ocorrência. A figura abaixo ilustra uma Transcrição para a interpretação do segmento textual: Ao invés disso, elas falam em aprender "sinais", [este é o sinal] como se os sinais fossem de alguma forma diferente das palavras. O intérprete sinaliza o termo SINAL [que é próprio do léxico da Libras e que, por sua vez, foi preservado no texto fonte] e em seguida faz uso da soletração como escolha tradutória para transcrevê-lo e explicitá-lo, mantendo o léxico e o sentido da referida palavra no texto alvo. No texto em português escrito o termo em questão encontra-se entre aspas, evidenciando um possível pertencimento à Libras. 


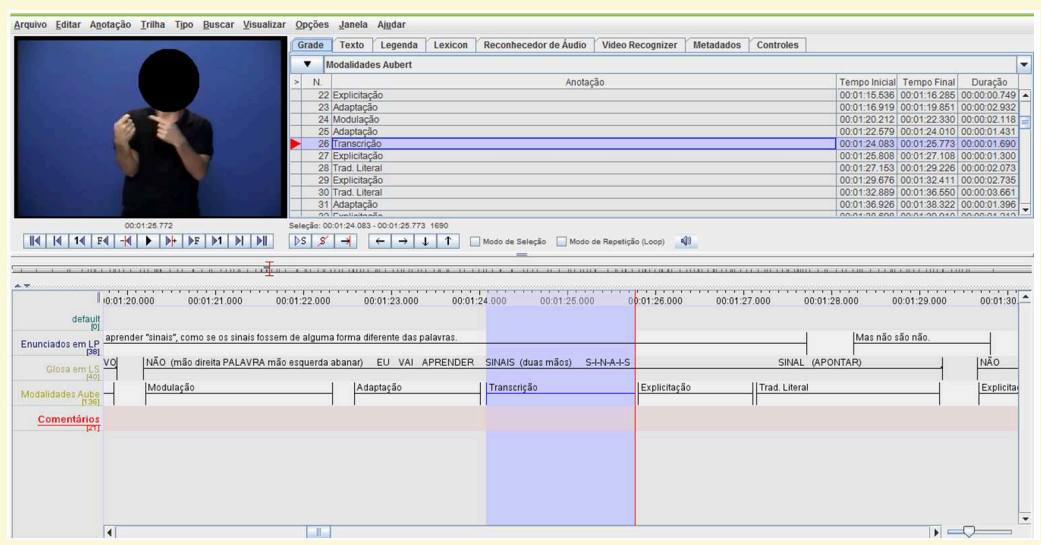

FIGURA 17 - Modalidade de Tradução: Transcrição

Fonte: Nicoloso (2015, p. 77)

O uso de Transposição, por sua vez, é bastante regular nas interpretações entre o par linguístico português e Libras. Esta modalidade consiste na mudança de categoria gramatical.

Esta modalidade ocorre sempre que pelo menos um dos três primeiros critérios que definem a tradução literal deixa de ser satisfeito, ou seja, sempre que ocorrem rearranjos morfossintáticos. Assim, por exemplo, se duas ou mais palavras forem fundidas em uma única ou, ao contrário, se uma palavra for desdobrada em várias unidades lexicais, ou se a ordem das palavras for alterada, ou se houver uma alteração de classe gramatical ou quaisquer combinações dos anteriores, por mais "literais" que os respectivos significados se apresentem, não constituirão segmentos textuais estruturalmente literais, sendo, assim, classificados como transposições. As transposições podem ser obrigatórias, impostas pela estrutura morfossintática da língua alvo, ou facultativas, a critério do tradutor. (AUBERT, 1998, p. 107). 
A imagem a seguir apresenta um exemplo da Modalidade de Tradução denominada Transposição. Para a interpretação da expressão "processo de aculturação", a intérprete faz um rearranjo morfossintático para o item lexical "aculturação". Ou seja, ela desmembra uma palavra [aculturação] em mais de uma unidade lexical e em outras categorias gramaticais, a fim de atingir uma proximidade quanto à correspondência semântica, sinalizando respectivamente: "PROCESSO MEDIAÇÃO AQUISIÇÃO TROCAR ADAPTAR CULTURA”. Nesse sentido, para conseguir a complexa tarefa de interpretar o significado do termo "aculturação" no português, foi necessário o uso de cinco morfemas na Libras.

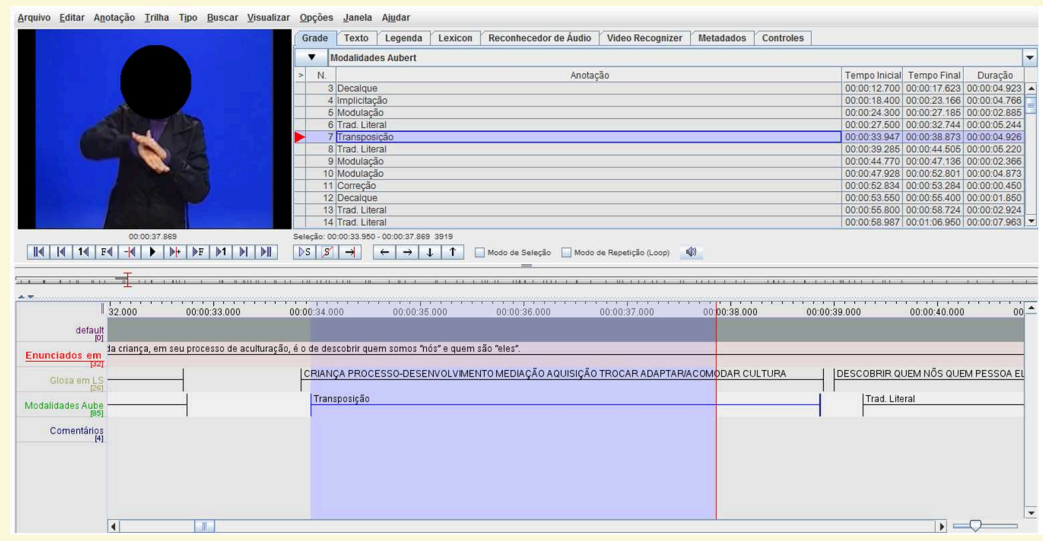

FIGURA 18 - Modalidade de Tradução: Transposição Fonte: Nicoloso (2015, p. 78)

Para cada exemplo de Modalidade de Tradução foram apresentados alguns elementos linguísticos da Libras que serviram para transmitir determinado enunciado resultando no uso de uma dessas modalidades. No entanto, elementos como a soletração manual, os marcadores não manuais [como as expressões faciais e corporais: direção do olhar, movimento da cabeça, sobrancelhas], o uso do espaço; os classificadores; a iconicidade; entre outros não citados neste artigo, não representam o universo da materialidade linguís- 
tica da Libras. Portanto, o contexto do discurso e o público envolvido na mensagem não podem ser separados dessas definições linguísticas.

\section{Considerações Finais}

Em relação às Modalidades de Tradução, pode-se afirmar que as transposições, tanto quanto as modulações, podem ser obrigatórias ou opcionais. Conforme Aubert (1998, p. 108) “uma hipótese ainda a ser adequadamente investigada sugere que as transposições e as modulações optativas representam parcela significativa da manifestação, no plano linguístico, da liberdade do tradutor".

Aubert propõe, ainda, uma divisão entre dois tipos gerais de métodos de tradução. Um é a tradução direta, em que é possível transpor um elemento da mensagem da língua fonte por outro elemento da língua alvo. Essas traduções são baseadas em categorias de paralelismo, que podem ser estruturais ou conceituais. Entretanto, há certos efeitos estilísticos que não podem ser transpostos para uma língua meta sem alguma espécie de alteração na ordem sintática ou ainda no léxico. Nesse caso a tradução é chamada tradução indireta ou oblíqua.

Segundo essa distinção, as modalidades de transcrição, empréstimo, tradução literal e transposição são coletivamente denominadas, por Aubert (1998), modalidades de tradução direta. As modalidades de explicitação/implicitação, modulação, adaptação e tradução intersemiótica, por sua vez, constituem o conjunto das modalidades de tradução indireta. Conforme mencionado anteriormente, essas modalidades de tradução podem ocorrer em estado "puro" ou de forma "hibrida" (AUBERT, 1998, p. 110).

As Modalidades de Tradução, tais como propostas por Aubert, sofreram algumas adaptações para satisfazer às necessidades específicas deste trabalho que se refere também à interpretação para as línguas de sinais e não somente a tradução de dois textos escritos. Para as necessidades impostas, que envolvem a interpretação si- 
multânea em língua de sinais, foram mantidas todas as modalidades sugeridas por Aubert (1998). Cabe reforçar, porém, que para a modalidade de tradução intersemiótica houve a necessidade de apoio em Segala (2010). A razão considerada para esse critério é que nas interpretações do texto selecionado não foi possível identificar a modalidade de Tradução Intersemiótica conforme descrita por Aubert, ou seja, por meio de traduções de ilustrações, logomarcas, selos, brasões e similares. Então, o procedimento de fazer uso das considerações de Segala (2010) para embasar teoricamente a Tradução Intersemiótica na Libras justifica-se pelo fato de que essa modalidade tal qual descrita por Aubert refere-se, prioritariamente, à tradução entre dois textos escritos.

Neste sentido, o presente trabalho não teve como proposta avaliar, comparar ou julgar a qualidade da atividade de interpretação simultânea. Conforme Aubert (1998, p. 125):

A despeito de seu poder de configurar dados significativos para a tradução, [...] há certas questões que, embora possam, à primeira vista, parecer talhadas para serem investigadas com o auxílio do modelo das modalidades de tradução, muito provavelmente seriam melhor atendidas adotando-se outras abordagens e formas de análise. Entre esses, cumpriria destacar:

[...]

b. a qualidade da tradução somente será sugerida indiretamente, pela maior ou menor incidência das categorias omissão e erro, sem, no entanto, determinar a maior ou menor relevância da tradução de cada palavra, frase ou oração omitida ou contendo erros referenciais, e, portanto, sem medir o efetivo alcance de tais problemas sobre a percepção do texto traduzido como um todo.

Contudo, o exercício de utilizar uma metodologia de análise que se aproprie das Modalidades de Tradução, segundo Aubert (1998), contribui para se obter uma visão mais clara entre as semelhanças 
(aproximações) e diferenças (distância/afastamento) existentes entre os pares linguísticos e culturais. Essa clareza de percepção promove, assim, a conscientização no ato tradutório que, por sua vez, baseia-se na função central de teorizar sobre tradução nos cursos de formação de tradutores e intérpretes.

À luz do exposto acima, pode-se sugerir que as Modalidades de Tradução mostram-se também como uma produtiva metodologia, não só para descrever, mas para analisar e explicar as escolhas e os processos envolvidos na tradução e na interpretação.

\section{Notas}

1. NICOLOSO, Silvana. Modalidades de tradução na interpretação simultânea da língua portuguesa para a língua de sinais brasileira: investigando questões de gênero (gender). Tese de Doutorado. Programa de Pós-Graduação em Estudos da Tradução, Universidade Federal de Santa Catarina, UFSC, 2015.

2. As Modalidades de Tradução descritas por Aubert (1998) também foram utilizadas pelas autoras do presente texto para investigar questões de gênero na interpretação da LP para a Libras, resultando em um artigo científico no capítulo do livro "Signed Language Interpreting in Brazil" (QUADROS, FLEETWOOD, METZGER, 2012), publicado pela Editora da Gallaudet University Press (Washington, DC) em sua coleção sobre Estudos da Interpretação.

3. Neste caso o termo "tradução" poderá facilmente ser substituído pelo termo "interpretação" sem nenhum prejuízo.

4. Neste contexto o termo "tradutor" poderá ser substituído pelo termo "intérprete" sem prejuízo algum.

5. A proposta classificatória de Aubert será elencada, neste artigo, por ordem alfabética. 
6. Segundo McCleary \& Viotti (2007) o software ELAN é uma ferramenta de anotação/transcrição que permite ao usuário criar, editar, visualizar e procurar anotações através de dados de áudio e vídeo. Ele "é um programa desenvolvido pelo Max Planck Institute for Psycholinguistics, da Holanda" (LEITE, 2008, p. 142), com o intuito de fornecer uma base tecnológica para a anotação e a exploração de gravações multimidiáticas.

7. Para possibilitar a transcrição dos dados da pesquisa optou-se por utilizar a glosa. Glosa é uma palavra que traduz aproximadamente o significado de outro signo, neste caso, os sinais da Libras. A Glosa Libras/Português é representada sempre com a escrita em maiúscula entre outras regras descritas por Felipe (2007). Assim, as palavras que se encontram em fonte maiúscula nos exemplos deste artigo serão para remeter ao sinal realizado em Libras, sendo esta a forma adotada neste trabalho para representar as glosas no sistema de transcrição em Libras. Segundo Rigo (2012) as glosas são um sistema de notação utilizado para transcrição das línguas de sinais e já bastante difundida e utilizada por pesquisadores em inúmeros estudos. Esse sistema possui regras convencionadas de utilização de caracteres para designar determinados elementos linguísticos.

\section{Referências}

ALBIR, A. H.; ALVES, F. Translation as a cognitive activity. In: MUNDAY, J. The Routledge Companion to Translation Studies. Routledge, p. 54-73, 2009.

AUBERT, F. H.. As (in) fidelidades da tradução: servidões e autonomia do tradutor. Campinas: Unicamp, 1994.

. Modalidades de Tradução: Teoria e Resultados. TradTerm. São Paulo: CITRAT/FFLCH-USP, v.5, nº.1, p. 99-128, 1998.

BARBOSA, D. M. Omissões na interpretação simultânea de conferência: Língua Portuguesa - Língua Brasileira de Sinais. Dissertação de Mestrado. Universidade Federal de Santa Catarina: UFSC/PGET, 2014. 
BARBOSA, H. G. Procedimentos técnicos da tradução: Uma nova proposta. Campinas: Pontes, 1990.

BASTIANETTO, P. C. Legibilidade textual e modalidades de tradução: teoria e prática. Rio de Janeiro: UFRJ, 2012.

BRANCO, S. de O. Diferenciais de poder e o empréstimo linguístico em traduções no Brasil. ANTARES: Letras e Humanidades, v.3, n. 6, jul./dez, p. 236-250, 2011.

CAMARGO, D. C. As Modalidades de Tradução e o Contexto Literário. TradTerm. São Paulo: CITRAT/FFLCH-USP, v. 3, p. 27-33, 1996.

COKELY, D. Sign language interpreter and interpreting. Monographs Series: Linstok Press, 1992.

FELIPE, T. A. Libras em contexto: curso básico [livro do estudante]. 8 ed. Rio de Janeiro: WalPrint Gráfica e Editora, 2007.

LEITE, T. A. de. A segmentação da língua de sinais brasileira (libras): um estudo linguístico descritivo a partir da conversação espontânea entre surdos. Tese de Doutorado, Universidade de São Paulo, São Paulo: USP: 2008.

LUCHI, M. Interpretação de descrições imagéticas: onde está o léxico? Dissertação de Mestrado, Universidade Federal de Santa Catarina: UFSC, Florianópolis, 2013.

MCCLEARY, L; VIOTTI, E. Transcrição de dados de uma língua sinalizada: um estudo piloto da transcrição de narrativas na língua de sinais brasileira (LSB). In: SALLES, H. (Org.) Bilinguísmo e Surdez. Questões linguísticas e educacionais. Goiânia: Cânone Editorial, p. 01-28, 2007.

NASCIMENTO, C. B. Empréstimos Linguísticos do Português na Língua de Sinais Brasileira - LSB: Línguas em Contato. Dissertação de Mestrado. Programa de Pós-Graduação em Linguística. Universidade de Brasilia: UNB, 2010.

NICOLOSO, Silvana. Modalidades de tradução na interpretação simultânea da língua portuguesa para a língua de sinais brasileira: investigando questões de 
gênero (gender). Tese de Doutorado. Programa de Pós-Graduação em Estudos da Tradução, Universidade Federal de Santa Catarina, UFSC, 2015.

PAGURA, R. J. A interpretação de conferências: interfaces com a tradução escrita e implicações para a formação de intérpretes e tradutores. DELTA - Revista de documentação de estudos em Linguística Teórica e Aplicada. São Paulo, v. 19, p. 209-236, 2003.

PÖCHHACKER, F. Introducing interpreting studies. London: Routledge, 2004.

QUADROS, R. M.; KARNOPP, L. B. Língua de sinais brasileira: estudos linguísticos. Porto Alegre: Artmed, 2004.

QUADROS, R. M.; FLEETWOOD, E.; METZGER, M. Signed Language Interpreting in Brazil, Washington, DC: Editora da Gallaudet University Press, 2012.

RIGO, N. S. Tradução Comentada: Traduzibilidade poética na interface libras português: aspectos linguísticos e tradutórios com base em "Bandeira Brasileira" de Pimenta (1999) de Saulo Xavier de Souza. Trabalho de Conclusão de Curso em Letras - LIBRAS. UFSC: Florianópolis, 2012.

SANTIAGO, V. A. A. Português e libras em diálogo: os procedimentos de tradução e o campo do sentido. In: ALBRES, N. A.; SANTIAGO, V. A. A. (Org) Libras em estudos: tradução/interpretação São Paulo: FENEIS, p. 35-55, 2012.

SEGALA, R. R. Tradução intermodal e intersemiótica/interlingual: Português brasileiro escrito para Língua Brasileira de Sinais. Dissertação (Mestrado em Estudos da Tradução). Universidade Federal de Santa Catarina - UFSC, 2010.

SOBRAL, A. Dizer o 'mesmo' a outros: ensaios sobre tradução. São Paulo: Special Books Service Livraria, 2008.

VASCONCELlOS, M. L.; BARTHOLAMEI, L. A. J. Estudos da Tradução I. Curso de Bacharelado em Letras/Libras - Florianópolis: UFSC, 2008.

VINAY, J.P.; DARBELNET, J. Stylistique comparée du français et de l'anglais: Méthode de Traduction. Paris: Didier/Beauchemin, 1960. 
WILCOX, S.; WILCOX, P. P. Aprender a ver: o ensino da língua de sinais americana como segunda língua. Tradução de Tarcísio de Arantes Leite. Rio de Janeiro: Editora Arara Azul, 2005.

Recebido em: 02/07/2015 Aceito em: 01/10/2015 